fulfilled SLE criteria. The immunological tests showed anti-nuclear antibodies among all patients with high titre and anti-DNA antibodies in SLE and CAH patients respectively. One RA patient had anti-Ro60 antibodies.

Conclusions: During our study, AAA were found fortuitously in AIRD. This association is rarely described in the literature. Hepatic involvement can be seen during AIRD. Nevertheless, a CAH and CD associated shouldn't be disregarded. References:

[1] Diagnostic value of anti-actin antibodies in a French multicenter study. P.Chretien-Leprince et al; Ann N Y Acad Sci. 2005;1050:266-73.

[2] Smooth-muscle antibodies in rheumatoid arthritis. I.Andresen et al; Acta Pathol. Microbiol. Scand. 1980;88: 131-135.

Disclosure of Interest: None declared

DOI: 10.1136/annrheumdis-2017-eular.6748

\section{SAT0109 QUANTITATIVE ESTIMATES OF DAMAGE AND DISTRESS, IN ADDITION TO INFLAMMATION, AND THE PROPORTION EACH OF THE 3 VARIABLES AFFECTS CLINICAL MANAGEMENT DECISIONS (TOTAL=100\%) MAY CLARIFY ASSESSMENT OF CLINICAL STATUS IN PATIENTS WITH RHEUMATOID ARTHRITIS (RA)}

K.A. Gibson ${ }^{1,2,3}$, I. Castrejon ${ }^{4}$, T. Pincus ${ }^{4} .{ }^{1}$ Rheumatology, Liverpool Hospital; ${ }^{2}$ ingham Research Institute, Liverpool; ${ }^{3}$ University of New South Wales, Sydney, Australia; ${ }^{4}$ Rheumatology, Rush University Medical Center, Chicago, United States

Background: Quantitative assessment in rheumatoid arthritis (RA) is directed to inflammatory activity (INF) and not to joint damage (DAM) and distress (STR seen as fibromyalgia, depression, etc.). However, DAM and STR may affect clinical management and outcomes of treatment in many RA patients. For example, an RA patient with well-controlled INF who has secondary fibromyalgia may have 0 swollen joints (SJC) and an ESR $\geq$ of 15 , but nonetheless have a DAS28 of 5.1, CDAI of $\geq 22$, and RAPID3 of $\geq 16$ (indicating high activity), based on 14/28 tender joints and a patient global assessment of 80/100. Therefore, quantitative estimates of DAM, and STR, as well as INF may clarify patient status and clinical management decisions.

Objectives: To analyze physician quantitative estimates for the proportion of management decisions attributed to INF, DAM, or STR (total=100\%) in RA patients seen in routine care.

Methods: At one academic rheumatology center, the rheumatologist completes four 0-10 visual analog scales (VAS) for overall global assessment (DOCGL), INF, DAM, and STR. In patients with DOCGL $\geq 2$, the proportion of management decisions are estimated as $\% \mathrm{INF}+\% \mathrm{DAM}+\% \mathrm{STR}=100 \%$. Cross-tabulations were computed for various phenotypes in $5 \mathrm{INF}+\mathrm{DAM}$ and INF+STR categories, 0 , $1-20 \%, 21-40 \%, 42-60 \%$, and $61-100 \%$.

Results: Among the 77 RA patients, $>40 \%$ of clinical management decisions were attributed to INF in only $31(40 \%)$, versus $>40 \%$ to DAM in $33(43 \%)$, and $>40 \%$ to STR in $17(22 \%)$ (Table). No category of INF+DAM or INF+STR included more than $20 \%$ of the patients, and patients were found in 17 of 25 possible categories for combinations of INF+DAM and INF+STR. The 13 patients (17\%) in whom INF was estimated to contribute $0 \%$ to management included 3 of 5 DAM and 5 of 5 STR categories (Table). The 23 patients with $1-20 \%$ of management attributed to INF included 4/5 DAM and 5/5 STR categories. The 10 with $21-40 \%$ INF included 4/5 DAM and 4 STR categories. The 16 with $41-60 \%$ attributed to INF included 3 DAM and 2 STR categories. Only 15 of the 77 patients (19\%) had $>60 \%$ attributed to INF.

Number among 77 RA patients with physician estimates of $\%$ inflammation, $\%$ damage and $\%$ distress (total $=100 \%$ ) in clinical management decisions ( $\%$ is of all patients)

\begin{tabular}{lcccccc}
\hline \% Inflammation: & 0 & $1-20 \%$ & $21-40 \%$ & $41-60 \%$ & $61-100 \%$ & Total \\
$\mathrm{N}$ & $13(17 \%)$ & $23(30 \%)$ & $10(13 \%)$ & $16(21 \%)$ & $15(19 \%)$ & 77 \\
\hline$\%$ Damage: & & & & & & \\
$0-20 \%$ & $3(4 \%)$ & $8(10 \%)$ & $5(6 \%)$ & $3(4 \%)$ & $14(18 \%)$ & $33(43 \%)$ \\
$21-40 \%$ & 0 & 0 & $2(3 \%)$ & $8(10 \%)$ & $1(1 \%)$ & $11(14 \%)$ \\
$41-60 \%$ & $3(4 \%)$ & $4(5 \%)$ & $1(1 \%)$ & $5(6 \%)$ & 0 & $13(17 \%)$ \\
$61-80 \%$ & 0 & $6(8 \%)$ & $2(3 \%)$ & 0 & 0 & $8(10 \%)$ \\
$81-100 \%$ & $7(9 \%)$ & $5(6 \%)$ & 0 & 0 & 0 & $12(16 \%)$ \\
$\%$ Distress: & & & & & & \\
$0-20 \%$ & $7(9 \%)$ & $13(17 \%)$ & $3(4 \%)$ & $15(19 \%)$ & $15(19 \%)$ & $53(69 \%)$ \\
$21-40 \%$ & $1(1 \%)$ & $2(3 \%)$ & $3(4 \%)$ & $1(1 \%)$ & 0 & $7(9 \%)$ \\
$41-60 \%$ & $2(3 \%)$ & $2(3 \%)$ & $2(3 \%)$ & 0 & 0 & $6(8 \%)$ \\
$61-80 \%$ & $1(1 \%)$ & $4(5 \%)$ & $2(3 \%)$ & 0 & 0 & $7(9 \%)$ \\
$81-100 \%$ & $2(3 \%)$ & $2(3 \%)$ & 0 & 0 & 0 & $4(5 \%)$ \\
\hline
\end{tabular}

Conclusions: Quantitative physician estimates of the proportion of clinical management decisions attributed INF, DAM, and STR may help clarify RA patient status and document a basis for clinical decisions. High levels of DAM and/or STR may explain in part why a target of RA remission often is not met in many patients seen in routine clinical care.

References:

[1] Tymms et al, Arth Care \& Res 66:190-196, 2014.

Disclosure of Interest: K. Gibson: None declared, I. Castrejon: None declared, T. Pincus Shareholder of: Health Report Services, Inc

DOI: 10.1136/annrheumdis-2017-eular.6239

\section{SAT0110 THE IMPACT OF PUMMONARY INVOLVEMENT TO THE TREATMENT OF REUMATOID ARTHRITIS}

K. Setoguchi ${ }^{1}$, F.Y. Chen ${ }^{1}$, S. Kamei ${ }^{1}$, M. Ogawa ${ }^{1}$, S. Kobayashi ${ }^{2} .{ }^{1}$ Systemic immunological diseases, Tokyo metropolitan Komagome Hospital; ${ }^{2}$ Allergy and Rheumatology, Graduate school of medicine, The University of Tokyo, Tokyo, Japan

Background: Standard treatment of patients with rheumatoid arthritis (RA) complicated with pulmonary involvements has not been clarified.

Objectives: To evaluate the influence of pulmonary involvement on immunological background and treatment of patients with RA

Methods: A cross-sectional study was conducted, in which medical records of 479 RA patients who visited our hospital during September the first to November 31th, 2016 were reviewed. Pulmonary involvements were diagnosed by imaging including plain chest radiography or chest computed tomography findings. Patients were divided into two groups, with or without pulmonary involvement, and compared with immunological background (serum level of rheumatoid factor (RF), anti-CCP antibody and recent treatment.

Results: Among 479 patients, pulmonary involvements were diagnosed in 158 patients (female $=116$ ), mean age was 73.4 (standard deviation (SD) 9.0) year old, and mean disease duration was 143.3 (SD 125.9) months. Pulmonary involvements included interstitial pneumonia $(\mathrm{N}=52)$, organizing pneumonia $(\mathrm{N}=11)$, airway diseases $(\mathrm{N}=36)$, old tuberculosis $(\mathrm{N}=18)$, nontuberculous mycobacteria $(\mathrm{N}=13)$, pleurisy $(\mathrm{N}=5)$. Higher anti-CCP titers were found in RA with pulmonary involvement than $R A$ only (medians $303.9 \pm 596.5$ versus $163.5 \pm 256.1 \mathrm{U} / \mathrm{mL}$, $P<0.001$ ), and the same result was found in RF (medians $322.5 \pm 437.2$ versus $157.9 \pm 277.5 \mathrm{IU} / \mathrm{mL}, \mathrm{P}<0.001)$. Methotrexate $(\mathrm{MTX})$ was less frequently used $(\mathrm{N}=56,35.4 \%$ versus $\mathrm{N}=205,63.9 \%, \mathrm{P}<0.001)$, but biological agents were more used $(\mathrm{N}=31,19.6 \%$ versus $\mathrm{N}=49,15.3 \%)$, especially abatacept (ABT) was highly used $(\mathrm{N}=15,9.5 \%$ versus $\mathrm{N}=8,2.5 \%)$

Conclusions: RA patients with pulmonary involvements had high immunological response and were less prescribed MTX with may injure lungs and more used ABT. Association between pulmonary involvement and high titer of ACPA, and between positivity for RF or ACPA and good response of ABT were reported. ABT may be useful treatment for RA patients with pulmonary involvement.

References:

[1] Gottenberg JE et al.: Arthritis Rheumatol.68 (6):1346-1352.2016.

[2] Rocha-Munoz AD et al.: J immunol Res. Epub 2015 May 19.

Disclosure of Interest: None declared

DOI: 10.1136/annrheumdis-2017-eular.3936

\section{SAT0111 CLARA CELL PROTEIN CC16 AND ITS PATHOGENIC ROLE IN BRONCHIAL OBSTRUCTION IN PATIENTS WITH RHEUMATOID ARTHRITIS}

K.V. Nochevnaya ${ }^{1}$, I.I. Nesterovich ${ }^{2}$, Y.D. Rabik ${ }^{2}$, A.A. Speranskaya ${ }^{3}$, V.P. Zolotnitskaya ${ }^{3}$, N.A. Amosova ${ }^{3}$, V.I. Amosov ${ }^{3}$, V.I. Trofimov ${ }^{2}$, T.D. Vlasov ${ }^{4}$ ${ }^{1}$ Hospital Therapy Department, Department of Pathophysiology; ${ }^{2}$ Hospital Therapy Department; ${ }^{3}$ Radiology Department; ${ }^{4}$ Department of Pathophysiology, Academician I.P. Pavlov First St. Petersburg State Medical University, Saint Petersburg, Russian Federation

Background: Bronchial obstruction (BO) is a common manifestation of lung involvement in rheumatoid arthritis (RA) with high incidence from 60 to $80 \%$ of all cases. However the pathogenesis of $\mathrm{BO}$ in patients with RA remains unknown. Serum level of protein CC16 produced by Clara cells in terminal bronchioles has been reported to decrease in BO associated with bronchial asthma, chronic obstructive pulmonary disease and others. CC16 was considered to demonstrate anti-inflammatory effect via inhibition of interferon-gamma, tumor necrosis factor alpha, interleukin 1 beta, neutrophil elastase and other proinflammatory factors Also it was shown that $\mathrm{CC} 16$ deficiency has a pathogenic effect in BO. In the same time the role of protein $\mathrm{CC} 16$ in the pathogenesis of autoimmune diseases (and RA) is not studied.

Objectives: We aimed to evaluate serum level of CC16 in patients with RA in dependence on the presence and severity of $\mathrm{BO}$.

Methods: Serum levels of CC16 in 66 patients with RA and 13 healthy controls were measured by enzyme linked immunoadsorbent assay (ELISA). Patients with RA underwent survey, physical examination and pulmonary function tests (PFTs) including spirometry and bronchodilator test with inhalation of salbutamol $(\mathrm{N}=41)$ and body plethysmography $(\mathrm{N}=11)$. Statistical processing was carried out using Spearman correlation coefficient and Mann-Whitney test. $P$ value $<0.05$ was considered as significant.

Results: More than $60 \%$ of participants with RA had BO in terminal bronchioles (small airway obstruction), which was revealed with changes of expiratory flows (forced expiratory volume in 1s (FEV1), forced expiratory flow (FEF) between $50 \%$ and $75 \%$ of forced vital capacity), residual volume (RV) and bronchial resistance (SGaw) in relation to proper values. Depression of post-bronchodilator $\mathrm{FEF}_{75 \%}$ lower than $70 \%$ was adopted as the main criterion of $\mathrm{BO}$. There were no differences ( $p$ value $>0,05$ ) between serum levels of CC16 in patients with RA $(20,14 \pm 1,49 \mathrm{ng} / \mathrm{ml})$ and control group $(22,70 \pm 2,13 \mathrm{ng} / \mathrm{ml})$. However in patient group those with $\mathrm{BO}$ had significantly lower levels of CC16 $(15,59 \pm 1,89$ compared with $27,43 \pm 2,81$ in patients without $\mathrm{BO}, \mathrm{p}$ value $<0,01)$. Lower $\mathrm{CC} 16$ was associated with decreased post-bronchodilator FEV1 and $\mathrm{FEF}_{75 \%}(r=0,345, p$ 
value $<0,05$ and $r=0,486, p$ value $<0,01$ respectively), depressed bronchial resistance SGaw $(r=0,773$, p value $<0,01)$ and increased $R V(r=-0,736$, $p$ value $<0,01$ ), which determined BO severity.

Conclusions: More than half of patients with RA have BO predominantly in terminal bronchioles. Accepting significant decrease of Clara cell protein $\mathrm{CC} 16$ in patients with RA having $\mathrm{BO}$ we suppose pathogenic relationship between functional depression of Clara cell anti-inflammatory activity and BO in this category of patients.

References:

[1] Park HY. Club cell protein 16 and disease progression in chronic obstructive pulmonary disease (2013).

Disclosure of Interest: None declared

DOI: 10.1136/annrheumdis-2017-eular.4585

\section{SAT0112 PREVALENCE AND INCIDENCE OVER 3 YEARS OF DIFFERENT COMORBIDITIES IN RHEUMATOID ARTHRITIS (RA): A 3 YEAR LONGITUDINAL STUDY IN 769 ESTABLISHED RA PATIENTS}

L. Gossec, M. Soubrier, F. Foissac, F. Fayet, N. Balandraud, T. Bardin, C. Beauvais, G. Chales, I. Chary-Valckenaere, E. Dernis, L. Euller-Ziegler, R.-M. Flipo, M. Gilson, T. Marhadour, X. Mariette, G. Mouterde, S. Pouplin, P. Richette, A. Ruyssen-Witrand, T. Schaeverbeke, C. Sordet, M. Dougados. COMEDRA working group, Paris, France

Background: Comorbidities including cardiovascular (CV) risk, cancer and osteoporosis are frequent in RA.[1]

Objectives: To quantify at baseline and 3 years later, the prevalence (at baseline) and incidence (over 3 years) of some selected comorbidities.

Methods: This was an open long term ( 3 years) extension of the COMEDRA 6-month randomized controlled trial in which patients with definite, stable RA were visiting a nurse for comorbidity counselling.[2] Comorbidity status was assessed through face-to-face interviews and nurses provided advice on screening and management, at baseline and 3 years later. The frequency of comorbidities was assessed at both timepoints and incidence of new cases was assessed as overall $\%$ of patients and as relative increase in the given comorbidity.

Results: Of the 970 recruited patients, $776(80 \%)$ were followed up at 2-4 years $(15,1.5 \%$, had died) and $769(79 \%)$ had available data for comorbidities at both timepoints: at baseline, mean $( \pm S D)$ age $58( \pm 11)$ years, mean disease duration $14( \pm 10)$ years; $614(80 \%)$ were women and $538(70 \%)$ were receiving a biologic with a mean DAS28 of $3.1 \pm 1.3$.

At baseline, the most frequent comorbidities were history of fracture $(31.9 \%)$ and high blood pressure $(30.9 \%)$ and at 3 years the comorbidity which had most increased (i.e., incidence) in this population aged around 60 years, was high blood pressure (4\%) whereas smoking had decreased (Table).

Table: frequency of comorbidities at baseline and 3 years later

\begin{tabular}{|l|c|c|c|}
\hline Comorbidity & $\begin{array}{c}\text { COMEDRA study } \\
\text { baseline (month 0 for } \\
\text { group I and month 6 } \\
\text { for group II) }\end{array}$ & $\begin{array}{l}\text { Follow-up at } \\
3 \text { years }\end{array}$ & $\begin{array}{l}\text { Absolute increase, \% of } \\
\begin{array}{l}769 \text { patients (relative } \\
\text { increase, \% of baseline } \\
\text { prevalence) }\end{array}\end{array}$ \\
\hline $\begin{array}{l}\text { Myocardial } \\
\text { infarct }\end{array}$ & $13(1.7)$ & $18(2.3)$ & $0.6(38.4)$ \\
\hline Angina & $9(1.2)$ & $17(2.2)$ & $1.0(88.9)$ \\
\hline Stroke & $16(2.1)$ & $29(3.8)$ & $1.7(81.2)$ \\
\hline $\begin{array}{l}\text { Obliterating } \\
\text { arteriopathy }\end{array}$ & $8(1.0)$ & $14(1.8)$ & $0.8(75.0)$ \\
\hline Diabetes & $39(5.1)$ & $50(6.5)$ & $1.4(28.2)$ \\
\hline $\begin{array}{l}\text { High Blood } \\
\text { Pressure }\end{array}$ & $238(30.9)$ & $270(35.1)$ & $4.2(13.4)$ \\
\hline Hyperlipidemia & $149(19.4)$ & $170(22.1)$ & $2.7(14.1)$ \\
\hline $\begin{array}{l}\text { Obesity } \\
\text { BMl>-30) }\end{array}$ & $114(14.8)$ & $124(16.1)$ & $1.3(8.8)$ \\
\hline Smoking & $120(15.6)$ & $104(13.5)$ & $-2.1(-13.3)$ \\
\hline Colon cancer & $2(0.3)$ & $2(0.3)$ & $0(0)$ \\
\hline Breast cancer & $23(3.0)$ & $27(3.5)$ & $0.5(17.4)$ \\
\hline Lung cancer & $1(0.1)$ & $2(0.3)$ & $0.2(100.0)$ \\
\hline Prostate cancer & $3(0.4)$ & $4(0.5)$ & $0.1(33.3)$ \\
\hline Uterus cancer & $7(0.9)$ & $7(0.9)$ & $0(0)$ \\
\hline $\begin{array}{l}\text { Skin cancer (all } \\
\text { types) }\end{array}$ & $26(3.4)$ & $36(4.7)$ & $1.3(27.8)$ \\
\hline Lymphoma & $2(0.3)$ & $3(0.4)$ & $0.1(50.0)$ \\
\hline $\begin{array}{l}\text { History } \\
\text { fracture }\end{array}$ & $245(31.9)$ & $256(33.3)$ & $1.4(4.5)$ \\
\hline
\end{tabular}

Conclusions: Comorbidities are frequent in RA though screening does not always address the most frequent or severe comorbidities. Efforts must be pursued to improve comorbidity screening and prevention.

References:

[1] Ref 1. Baillet A, Gossec L et al. Ann Rheum Dis. 2016;75(6):965-73.

[2] Ref 2. Dougados M, Soubrier M, et al. Ann Rheum Dis. 2015;74(9):1725-33.

Acknowledgements: grant from Roche France and from the French National Research Program (PHRC AOM 12072).

Disclosure of Interest: None declared

DOI: 10.1136/annrheumdis-2017-eular.2978

\section{SAT0113 OBESITY AND METABOLIC SYNDROME INFLUENCE ON N-TERMINAL PRO-BRAIN NATRIURETIC PEPTIDE LEVELS IN RHEUMATOID ARTHRITIS PATIENTS}

L. Kondratyeva, T. Popkova, I. Kirillova, D. Novikova, A. Novikov, E. Alexandrova E. Nasonov. V.A. Nasonova Research Institute of Rheumatology, Moscow, Russian Federation

Background: N-terminal pro-brain natriuretic peptide (NT-proBNP) is a recognized myocardial injure marker, a known predictor of heart failure and cardiovascular death. Rheumatoid arthritis (RA) patients (pts) were shown to have higher than in general population NT-proBNP concentrations, positively correlating with IL-6 levels. Adipose tissue is considered be one of the sources of this pro-inflammatory cytokine. But on the other hand, metabolic syndrome (MS) and obesity, which also occur in RA pts, are usually associated with lower NT-proBNP levels in general population.

Objectives: To find out whether overweight/obesity or MS may modify NT-proBNP levels in RA pts.

Methods: A total of 68 early RA pts $(72 \%$ females, $28 \%$ males) was enrolled in the study. Mean disease duration was $6[4 ; 8]$ months, and RA activity using DAS28 calculator was $5,6[5,1 ; 6,4]$ scores. The majority of pts had positive RF $(87 \%)$ and ACPA (88\%). All pts were glucocorticoids and disease-modifying antirheumatic drugs - naïve prior to inclusion. The overweight/obesity was determined by WHO criteria in patients with body mass index (BMI) $\geq 25$ $\mathrm{kg} / \mathrm{m}^{2}$. National Cholesterol Education Program/Adult Treatment Panel III criteria were used to confirm MS. Serum levels of NT-proBNP $(\mathrm{pg} / \mathrm{mL})$ were measured using electrochemiluminescence test Elecsys proBNP II (Roche Diagnostics, Switzerland). NT-proBNP levels $>125,0 \mathrm{pg} / \mathrm{mL}$ were considered as elevated.

Results: Overweight and obesity were established in $54,4 \%$ RA pts. Overweight/obese RA pts were older than pts with normal BMI (57 [53;61] years vs $48[34 ; 61]$ years, $p=0,02)$, had higher DAS28 scores $(5,85[5,20 ; 6,57]$ vs $5,28[4,76 ; 5,69], p<0,01)$, higher CRP $(38,8[14,3 ; 47,9] \mathrm{mg} / \mathrm{L}$ vs $12,8[2,2 ; 28,8]$ $\mathrm{mg} / \mathrm{L}, p<0,01)$. Elevated NT-proBNP concentrations were found in $62,2 \%$ overweight/obese pts vs $29,0 \%$ pts with normal weight $(p<0,01)$, median NT-proBNP concentrations were $153,4[87,3 ; 236,9] \mathrm{pg} / \mathrm{mL}$ vs $75,2[40,2 ; 147,4] \mathrm{pg} / \mathrm{mL}$, respectively $(p=0,02)$. MS was established in $62,2 \%$ pts with $\mathrm{BMI} \geq 25 \mathrm{~kg} / \mathrm{m}^{2}$ and in $25,8 \%$ pts with $\mathrm{BMl}<25 \mathrm{~kg} / \mathrm{m}^{2} \quad(p<0,01)$. Median NT-proBNP concentrations did not vary significantly in pts with and without MS, whether they were overweight/obese $(p=0,75)$, or had normal $\mathrm{BMI}(p=0,27)$. Although higher rates of elevated NT-proBNP concentrations were documented in pts with MS $(61,3 \%$ vs $35,1 \%, p=0,03)$. NT-proBNP levels positively correlated with waist circumference $(r=0,33, p<0,01)$, ESR $(r=0,25, p=0,04)$, and CRP $(r=0,3, p=0,01)$.

Conclusions: Overweight and obesity in RA pts were associated with increased NT-proBNP levels. Abdominal obesity was identified as the only MS component, influencing NT-proBNP levels, presumably via up-regulation of the inflammatory process.

Disclosure of Interest: None declared

DOI: 10.1136/annrheumdis-2017-eular.3731

\section{SAT0114 POOR CARDIOVASCULAR RISK MANAGEMENT IN RHEUMATOID ARTHRITIS PATIENTS DESPITE AN EXPLICIT CARDIOVASCULAR RISK MANAGEMENT PROGRAM}

M. Heslinga ${ }^{1}$, I. van den Oever ${ }^{1}$, E. Griep ${ }^{2}$, H. Griep-Wentink ${ }^{2}$, Y. Smulders ${ }^{3}$, W. Lems ${ }^{1,4}$, M. Boers ${ }^{1,4}$, A. Voskuyl $^{4}$, M. Peters ${ }^{3}$, D. van Schaardenburg ${ }^{1}$, M. Nurmohamed ${ }^{1,4} .{ }^{1}$ Amsterdam Rheumatology and immunology Center $/$ Reade, Amsterdam; ${ }^{2}$ Antonius Hospital Zuidwest Friesland, Sneek; ${ }^{3} \mathrm{VU}$ University Medical Center; ${ }^{4}$ Amsterdam Rheumatology and immunology Center I VU University Medical Center, Amsterdam, Netherlands

Background: In 2011, we started a cardiovascular (CV) risk management program for rheumatoid arthritis (RA) patients visiting Reade in the Netherlands. We previously reported the presence of under treatment of hypercholesterolemia and hypertension [1].

Objectives: To assess the effectiveness of our $\mathrm{CV}$ risk management program after one year.

Methods: CV risk screening was performed at baseline and we informed the general practitioner (GP) about the results, including advices regarding the initiation of cardio preventive drugs. In high risk patients, antihypertensives were recommended when systolic blood pressure $>140 \mathrm{~mm} / \mathrm{Hg}$ and statins were recommended when low-density lipoprotein $>2.5 \mathrm{mmol} / \mathrm{l}$. The decision to start preventive medication was left to the GP. CV risk screening was repeated after one year. Patients completed a questionnaire about the actions that were taken following the results of the initial screening.

Results: Of the 266 patients $202(76 \%)$ were female, the mean age was $58 \pm 11$ years. After one year, 88 out of 134 patients who received inadequate or no treatment at baseline were still untreated or undertreated. Of the $188(71 \%)$ patients who were at high $\mathrm{CV}$ risk and who did have an indication to start therapy, only $7.5 \%$ was contacted by their GP and another $6.8 \%$ arranged an appointment themselves. While the 10-year CV risk did not decrease in the group as a whole, a risk reduction was found in the patients that started medication. Remarkably, $42 \%$ of patients reported lifestyle changes, including more exercise $(20 \%)$, diet adaption (16\%) and weight loss (9\%).

Conclusions: It is striking that one year after the introduction of our CV risk 